\title{
Sacrum w „Mieście bez Boga”
}

\section{Sacrum in a "City without God”}

\section{Streszczenie}

W kształtowaniu założeń urbanistycznych realizmu socjalistycznego aspekt sacrum z różnych przyczyn był zwykle deprecjonowany i marginalizowany. Celem pracy jest próba zmierzenia się z tą problematyką na przykładzie założenia urbanistycznego - Nowej Huty. Poruszone tematy będą dotyczyć genezy pojawienia się obiektów lub miejsc kultu religijnego w Nowej Hucie - „mieście bez Boga” oraz wyboru ich lokalizacji, aspektu współczesnego bytu tych obiektów jako elementu tkanki miejskiej, ich wpływu na oryginalny plan Nowej Huty, krajobraz miejski i poszczególne wnętrza, a także konserwacji i kreacji najbliższego im otoczenia.

Słowa kluczowe: sacrum, przestrzeń, Nowa Huta

\begin{abstract}
In shaping the urbanistic assumptions of socialist realism, the aspect of the sacred was often overlooked or marginalized for various reasons. This presentation is an attempt to tackle this problem on the example of urban planning - Nowa Huta. The topics discussed will be related to the origins of religious worship in Nowa Huta - the "city without God", the choice of the siting of such objects as well as the aspect of the contemporary existence of these spaces, their preservation, and creation in today's reality.
\end{abstract}

Keywords: sacrum, space, Nowa Huta 


\section{WSTĘP}

Wielkim fenomenem Nowej Huty jest niewątpliwie jej sfera sacrum. Mimo iż od początku była planowana jako ośrodek miejski bez świątyń i miejsc kultu religijnego, od początku jej istnienia, roku 1949, aż do dziś, na jej terenie zbudowano aż 9 kościołów. Obecność sakralnych budowli w przestrzeni architektonicznej i urbanistycznej ówczesnego miasta, dziś jednej z dzielnic miasta Krakowa, nie może być rozpatrywana z pominięciem aspektów zarówno społecznych, jak i historycznych powstawania kolejnych świątyń. Analizując plan Nowej Huty przygotowany w 1951 roku przez zespół architektów pod kierownictwem Tadeusza Ptaszyckiego, nie dostrzeżemy na nim kościoła, ponieważ do 1956 roku nie planowano jego budowy. Było to radykalne podejście władz, aby w miejscu o chrześcijańskich tradycjach, nie znajdowało się żadne miejsce kultu religijnego. To wyraz stosunku nowej władzy do Kościoła, której celem była całkowita laicyzacja społeczeństwa i zmuszenie do rezygnacji z praktyk religijnych. Katolicyzm był postrzegany przez władze jako wróg nowego systemu. Ideologia socjalistyczna, odrzucając istnienie Boga ${ }^{1}$, popierając ateizm, urzeczywistniała założenia Karola Marksa, który religię określał jako „opium dla ludu”, zbiór złudzeń mających na celu uśmierzenie cierpienia, a także przeszkodę w zdobywaniu szczęścia ludziom. Jako dopust Boży dla mieszkańców Mogiły, Pleszowa czy Czyżyn, które to wsie zostały wchłonięte przez Nową Hutę, należy rozpatrywać już wybór miejsca jej powstania. Urodzajne żyzne ziemie, pokryte łanami zbóż, w czerwcu 1949 roku, niedojrzałe, zostały skoszone, a malowniczy wiejski pejzaż został zamieniony na ogromny plac budowy nowego miasta i huty stali, w ludzkich umysłach jawił się przede wszystkim jako strach przed przyszłością. W okresie powojennym represje i prześladowania Kościoła były widoczne nie tylko w Polsce, ale także w innych częściach Europy. Przykładem i potwierdzeniem niechęci władz do obiektów sakralnych są losy Kościoła św. Szymona i Heleny w Mińsku, na Białorusi. Neoromańska świątynia zbudowana na początku XX wieku, po zajęciu Mińska przez wojska radzieckie została zamieniona na kino „Sawieckaja Biełarus”, gdzie po przebudowie w prezbiterium urządzono toalety i palarnię. Ten precedens pokazuje, jak bardzo władze nie traktowały kościołów jako swoistego sacrum.

Celem pracy jest ocena stanu zachowania i aranżacji przestrzeni wokół kościołów, jak również ich wpływ na tkankę miejską. Badania przeprowadzono na 9 obiektach sakralnych znajdujących się w dzielnicach Krakowa, Nowej Hucie, Mistrzejowicach, Bieńczycach, Czyżynach i Wzgórzach Krzesławickich. Przeprowadzone badania zostały poparte o pisane źródła historyczne, jak również interesujące przekazy ustne. W czterech przypadkach porównano również pierwotny plan Nowej Huty Tadeusza Ptaszyckiego z mapą sytuacyjną z roku 1961 i współczesnym układem (II. 1), a w reszcie przypadków mapę z 1961 roku ze współczesnym układem. 


\section{RELIGIA W NOWEJ HUCIE}

Ośrodki kultu religijnego Nowej Huty, poza opactwem Cystersów w Mogile, to przede wszystkim kościoły dokumentujące dzieje walki mieszkańców z władzą socjalistyczną. Są one niejako świadectwem przywiązania społeczności do tradycji katolickiej i jego determinacji w próbie zwalczenia desakralizacyjnej doktryny socjalizmu. Tożsamość Nowej Huty przez lata kształtowały dwa przeciwstawne, ścierające się ze sobą wzorce, z jednej strony władze państwowe tworzyły ją jako sztandarowy przykład nowoczesnego, socjalistycznego miasta, w którym nie ma miejsca dla Boga, z drugiej strony, społeczeństwo walczyło o przestrzeń zgodną z sakralną hierarchią i swoimi duchowymi potrzebami.

Proces formowania przestrzeni sacrum Nowej Huty postępował niezwykle wolno. W czerwcu, gdy kopano fundamenty pod pierwszy nowohucki blok mieszkalny, okoliczne wsie należały do dekanatu mogilskiego. W pobliżu terenów budowy nowego miasta znajdował się kościół parafialny św. Bartłomieja w Mogile i położony nieopodal kościół klasztorny oo. Cystersów. Nieco dalej położone były kościoły parafialne w Pleszowie i Ruszczy oraz wybudowany w latach 1936-1939 kościół w Czyżynach. We wsi Bieńczyce znajdowała się niewielka kaplica urządzona w dworku wybudowanym na początku XIX przez Komisję Włościańską. Oficjalna erekcja kaplicy odbyła się 21 marca 1947 roku².

Poza tymi świątyniami w nowobudowanym mieście nie zostało przewidziane żadne miejsce kultu religijnego. Równocześnie z budową nowego miasta zaczęła napływać do niego ludność zarówno z okolicznych wsi, jak i innych miast Polski, o przewadze młodych osób stanu wolnego, a to wraz z koncepcją miasta pozbawionego Boga, stanowiło nowe, niewątpliwie jedno z trudniejszych wyzwań nie tylko dla krakowskiego, ale także dla polskiego Kościoła.

Nasilające się przez lata prześladowania Kościoła w Polsce, których następstwem stał się szeroko nagłaśniany w ówczesnej prasie proces zatrzymanych krakowskich księży, poprzedzony rewizją pomieszczeń krakowskiej Kurii Metropolitalnej, nie zniechęciły jednak społeczeństwa³.

Prośby ówczesnego biskupa, Franciszka Jopa, kierującego diecezją, składane pisemnie do premiera Józefa Cyrankiewicza o wyrażenie zgody na budowę kościoła w Nowej Hucie, nie zostały spełnione. O niechęci władz wobec tej sugestii może świadczyć fakt, że nie pomógł również list współpracującego z rządzącymi, krakowskiego duchownego - ks. Stanisława Hueta ${ }^{4}$.

Nowe nadzieje na liberalizację polityki państwa przyniosły konsekwencje polityczne czerwca i października roku 1956. Rządzący w tym czasie państwem Władysław Gomułka, na początku listopada tego samego roku pozytywnie rozpatrzył postulat dwunastoosobowej delegacji parafian w sprawie zezwolenia na budowę nowohuckiej świątyni, które zostało pisemnie wysłane w grudniu. 23 stycznia 1957 roku Biuro Projektów „Miastoprojekt” sporządziło dokument w sprawie lokalizacji kościoła. Po przeprowadzeniu wizji lokalnych w terenie ustalono wstępną lokalizację na terenie os. C-1, przy skrzyżowaniu ulic Majkowskiego i Marksa ${ }^{5}$, w pobliżu teatru Kameralnego ${ }^{6}$. 
Zgodnie z zaleceniami Prezydium Rady Nadzorczej Miasta Krakowa projekt kościoła stał się tematem ogólnopolskiego konkursu architektonicznego, w wyniku którego wyłoniony został projekt inż. Zbigniewa Solawy z Krakowa. Na placu przyszłej budowy 17 marca 1957 roku uroczyście ustawiono symboliczny dla kultury chrześcijańskiej krzyż. Niestety wypowiedziane wówczas słowa ks. Stanisława Kościelnego „Wzięliśmy na swoje barki krzyż i mamy ten krzyż dźwigać, aż do szczęśliwego zakończenia"7 dały niedługo trwającą nadzieję. Już w roku 1959 nie uzyskał on zgody na procesję Bożego Ciała, a sam został odwołany z pełnionego przez siebie stanowiska proboszcza.

Dramat, który rozegrał się na nowohuckich ulicach po 19 kwietnia 1960 roku, rozbudził w społeczeństwie jeszcze większą wolę walki w obronie jego sumień i praw. Bez wątpienia stał się początkiem dla budowy nowohuckich świątyń. Tego dnia nowy inwestor pisemnie zażądał od parafii usunięcia krzyża z terenu, argumentując to decyzją o utworzeniu w tym miejscu tzw. szkoły tysiąclatki ${ }^{\text {. }}$

27 kwietnia 1960 roku od godziny 8.30 przez cały dzień, aż do północy, trwały zamieszki między mieszkańcami Nowej Huty a milicją, związane z próbą usunięcia krzyża z placu przeznaczonego pod budowę pierwszej nowohuckiej świątyni. Chcąc złamać opór protestującego społeczeństwa, milicjanci wspierani przez wojsko, atakowali ludzi stojących pod krzyżem śpiewających pieśni patriotyczne i religijne, zarówno gazem łzawiącym, jak i armatkami wodnymi, do protestujących strzelano z ostrej amunicji, a nocą w całej dzielnicy przeprowadzono aresztowania. W wydarzeniach wzięło udział około 2 tysięcy mieszkańców Nowej Huty, aresztowano 496 osób, a 87 osób zostało skazanych na kary od 6 miesięcy do 5 lat więzienia. Obrona krzyża była szokiem dla ówczesnych władz komunistycznych, których wizja o wzorcowym mieście bez Boga została zachwiana.

\section{KOŚCIOŁY W NOWEJ HUCIE}

Dopiero w 1965 roku, ówczesny administrator parafii - ks. Józef Gorzelany wraz z metropolitą krakowskim ks. abp. Karolem Wojtyłą przystąpił do budowy kościoła. Po wydaniu ostatecznej zgody, jeszcze w tym samym miesiącu, zaakceptowano projekt architekta Wojciecha Pietrzaka i Ewy Podolakowej. Choć władze państwowe utrudniały prace nad nową świątynią, nie pozwalając na wypożyczanie przez przedsiębiorstwa ciężkiego sprzętu, to dzięki organizacji ks. Gorzelanego, dyplomacji ks. kard. Wojtyły, pracowitości parafian i datkom pieniężnym od Polonii i katolików z Zachodu, po 10 latach budowy, w obecności 70 tysięcy wiernych, 15 maja 1977 roku, ks. kardynał Karol Wojtyła konsekrował pierwszy kościół w Nowej Hucie - pw. Matki Bożej Królowej Polski, nazwanego Arką Pana, bo „płynącego jak arka na morzu zła ponad wodami historii". Ten moment stał się niejako symbolem wygranej walki o Kościół, toczonej przez lata między nowohuckim społeczeństwem, a komunistyczną władzą ${ }^{9}$. 
Drugim kościołem powstałym w Nowej Hucie, którego budowa rozpoczęła się rok przed konsekracją Arki Pana, w roku 1976, był kościół pw. św. Maksymiliana Marii Kolbego. Genezy jego powstania doszukiwać się można już w oku 1970, kiedy to ks. Józef Kurzeja, wikariusz parafii, oddalonej o 5 kilometrów, w Raciborowicach, na terenie lasku akacjowego wybudował zielony, drewniany barak o wymiarach $5 \times 6$ metrów, nazwany przez mieszkańców osiedla „zieloną budką"10, który miał pełnić rolę małego kościoła. Na projekt właściwego kościoła rozpisano konkurs architektoniczny, który wygrał projekt Józefa i Anny Dutkiewicz. Znajduje się on w północno-zachodniej części osiedla, kilkadziesiąt metrów od układów mieszkaniowych.

Kolejnym Kościołem powstałym na Nowym Hucie w latach 80. jest kościół pw. Miłosierdzia Bożego, budowany w latach 1982-1987, według projektu Witolda Cęckiewicza i Andrzeja Lorka ${ }^{11}$. Kościół został usytuowany na wzgórzu, na skraju osiedla, sąsiadując jednocześnie z terenami zielonymi, jak również główną arterią komunikacyjną. Plac przed kościołem, dzięki dwóm podjazdom unoszącym się na coraz większych półkolistych arkadach, ujmujących plac w formie półkola i tworzących dziedziniec porośnięty murawą, ma niezwykle monumentalny charakter. Przeszklone przestrzenie otwierają się na otaczającą zieleń, dzięki czemu widoczna jest niezwykła korelacja wnętrza świątyni i jej zewnętrznego otoczenia. Projekt ten ukazuje słuszność i celowość pojmowania bryły jako całości z otaczającą ją przestrzenią.

Kolejnym kościołem, na który rozpisano konkurs architektoniczny w 1980 roku, był kościół pw. Matki Bożej Częstochowskiej. Z dwóch propozycji, krakowskiej i warszawskiej, na świątynię mającą powstać na osiedlu Szklane Domy, jury pod kierownictwem profesora Witolda Cęckiewicza wybrało drugą. Kościół budowany był w latach 1984-1994 według projektu Krzysztofa Dygi i Andrzeja Nasfetera ${ }^{12}$. Rozrzeźbiona ceglana bryła budynku z przeszkloną konstrukcją dachową stanowi kontrast do otaczających ją prostych brył układów mieszkaniowych. Otoczenie budynku zostało podporządkowane użyteczności i praktyczności, nie kładąc nacisku na estetykę. Stąd wokół kościoła nie znajduje się projektowana zieleń, a na znacznej przestrzeni znajduje się nawierzchnia z kostki brukowej, o niewielkich walorach estetycznych.

Następny kościół jest kolejnym kościołem zaprojektowanym przez Witolda Cęckiewicza. Kościół pw. św. Brata Alberta zbudowany w latach 1985-1994 ${ }^{13}$. Zlokalizowany został na nieużywanym lotnisku, na osi prostopadłej do pasa startowego. W jego najbliższym otoczeniu znajdują się czterokondygnacyjne bloki mieszkaniowe osiedla Dywizjonu 303. Swoją prostą, kubistyczną bryłą kościół wpisuje się w otoczenie. Obiegająca dookoła droga dojazdowa obsadzona została drzewami. Współautorem projektu otoczenia był Bolesław Figiel, dzięki któremu rosną tam klony złotolistne, graby, świerki, a także krzewy takie jak migdałowiec, ligustr czy tuja.

W latach 1991-1993 wybudowany został kościół pw. Matki Bożej Nieustającej Pomocy projektu architekta Marcina Stępniewskiego-Jankowskiego we współpracy z konstruktorem prof. Zbigniewem Jankowskim ${ }^{14}$. Jako miejsce wyznaczono niewielkie wzniesienie na skraju osiedla Bohaterów Września. Jest to kościół orientowany. Wokół kościoła zauważalna jest 
spójność i harmonia w kompozycji zieleni projektowanej. Główna brama została podkreślona przez niski szpaler z tui i jałowców, które zostały zastosowane również wzdłuż ogrodzenia. Szpaler wysokich tui odwraca uwagę od części kościoła pełniącej funkcje administracyjne.

Na osiedlu Kalinowym powstał kościół pw. św. Józefa projektu Zofii Łuczyńskiej i Jana Kurka. Ostateczna wersja projektu powstała w 1991 roku, natomiast kościół został ukończony w roku $2002^{15}$. Bryła budynku nawiązująca do krzyża łacińskiego oraz kompleks zabudowań parafialnych założony na rzucie litery L, otoczone są zielenią, która kontrastuje z czerwoną dachówką pokrywającą dach i kremową elewacją. Dookreśla ona sakralny charakter świątyni, nadając tym samym atmosferę swojskości.

Kościół pw. Najświętszego Serca Pana Jezusa jest najmniejszym, mającym zaledwie $424 \mathrm{~m}^{2}$, kościołem Nowej Huty. Wybudowany został w latach 1998-2001 według projektu Krzysztofa Ingardena i Przemysława Gawora, przy współpracy Jacka Ewy, który to projekt wygrał konkurs w roku $1997^{16}$. Jest on znamienny na wzgląd na historię religii w Nowej Hucie, ze względu na jego położenie w narożniku ul. Obrońców Krzyża i Ludźmierskiej, gdzie niegdyś miała powstać pierwsza świątynia Nowej Huty i gdzie toczyła się walka o krzyż. Niewielką przestrzeń wokół kościoła pokrywa nawierzchnia z kwadratowych płyt betonowych, a także kilka drzew liściastych.

Ostatnim kościołem powstałym na Nowej Hucie w roku 2001 jest kościół pw. Matki Bożej Pocieszenia. Projekt wykonał w 1998 roku Witold Cęckiewicz ${ }^{17}$, we współpracy Jana Grabackiego. W sąsiedztwie kościoła znajdują się głównie budynki mieszkaniowe jednorodzinne i budynki gospodarcze. Bryła budynku przesunięta jest na zachód od osi wyznaczonej przez aleję Róż, a tuż za nią znajduje się budynek parafialny, który swoją formą mocno kontrastuje z kościołem i nie wpisuje się w całość założenia. Niestety nie został zrealizowany projekt otoczenia kościoła i ośrodka parafialnego, który zakładał szpaler drzew będący odbiciem obłej w narysie elewacji.

Wykaz analizowanych kościołów wraz z ich adresami, datami powstania i projektantami znajduje się poniżej.

Tabela 1. Wykaz analizowanych kościołów

\begin{tabular}{|c|c|c|c|c|}
\hline Lp. & Kościół & $\begin{array}{c}\text { Adres } \\
\text { dzielnica }\end{array}$ & $\begin{array}{c}\text { Data } \\
\text { powstania }\end{array}$ & Projektant \\
\hline 1 & 2 & 3 & 4 & 5 \\
\hline 1. & $\begin{array}{c}\text { Matki Bożej } \\
\text { Królowej } \\
\text { Polski }\end{array}$ & $\begin{array}{c}\text { ul. Obrońców Krzyża 1 } \\
\text { Bieńczyce }\end{array}$ & $1967-1977$ & $\begin{array}{c}\text { Wojciech Pietrzyk } \\
\text { Ewa Podolakowa }\end{array}$ \\
\hline 2. & $\begin{array}{c}\text { Św. Maksymiliana } \\
\text { Marii Kolbego }\end{array}$ & $\begin{array}{c}\text { os. Tysiąclecia 86 } \\
\text { Mistrzejowice }\end{array}$ & $1976-1983$ & $\begin{array}{c}\text { Józef Dutkiewicz } \\
\text { Anna Dutkiewicz }\end{array}$ \\
\hline 3. & $\begin{array}{c}\text { Miłosierdzia } \\
\text { Bożego }\end{array}$ & $\begin{array}{c}\text { os. Na Wzgórzach 1A } \\
\text { Wzgórza Krzesławickie }\end{array}$ & $1982-1987$ & $\begin{array}{c}\text { Witold Cęckiewicz } \\
\text { Andrzej Lorek }\end{array}$ \\
\hline 4. & $\begin{array}{c}\text { Matki Bożej } \\
\text { Częstochowskiej }\end{array}$ & $\begin{array}{c}\text { os. Szklane Domy 7 } \\
\text { Nowa Huta }\end{array}$ & $1984-1994$ & $\begin{array}{c}\text { Krzysztof Dyga } \\
\text { Andrzej Nasfeter }\end{array}$ \\
\hline
\end{tabular}




\begin{tabular}{|c|c|c|c|c|}
\hline 1 & 2 & 3 & 4 & 5 \\
\hline 5. & Św. Brata Alberta & $\begin{array}{c}\text { os. Dywizjonu } 30363 \\
\text { Czyżyny }\end{array}$ & 1985-1994 & Witold Cęckiewicz \\
\hline 6. & $\begin{array}{c}\text { Matki Bożej } \\
\text { Nieustającej } \\
\text { Pomocy }\end{array}$ & $\begin{array}{l}\text { Os. Boh. Września } 33 \\
\text { Mistrzejowice }\end{array}$ & 1991-1993 & $\begin{array}{l}\text { Marcin Stępniewski-Markowski } \\
\text { Zbigniew Jankowski }\end{array}$ \\
\hline 7. & Św. Józefa & $\begin{array}{l}\text { os. Kalinowe } 5 \\
\text { Bieńczyce }\end{array}$ & 1991-2002 & $\begin{array}{l}\text { Zofia Łuczyńska } \\
\text { Jan Kurek }\end{array}$ \\
\hline 8. & $\begin{array}{c}\text { Najświętszego } \\
\text { Serca } \\
\text { Pana Jezusa }\end{array}$ & $\begin{array}{l}\text { Ludźmierska } 2 \\
\text { Nowa Huta }\end{array}$ & 1998-2001 & $\begin{array}{l}\text { Krzysztof Ingarden } \\
\text { Przemysław Gawor }\end{array}$ \\
\hline 9. & $\begin{array}{l}\text { Matki Bożej } \\
\text { Pocieszenia }\end{array}$ & $\begin{array}{l}\text { Bulwarowa 15a } \\
\text { Bieńczyce }\end{array}$ & 2001 & Witold Cęckiewicz \\
\hline
\end{tabular}

\section{PRZESTRZENIE WOKÓŁ NOWOHUCKICH KOŚCIOŁÓW}

Wykonana analiza wykazała, że wszystkie badane kościoły znajdują się w niewielkiej odległości od zabudowań, zwykle mieszkalnych oraz usługowych. W większości są to wielokondygnacyjne budynki mieszkalne z połowy i końca XX wieku. Wyjątkiem jest kościół pw. Matki Bożej Pocieszenia, wokół którego znajdują się niewysokie budynki mieszkalne jednorodzinne oraz niewielkie budynki gospodarcze.

Wśród nich znajduje się jeden wpisany do gminnej ewidencji zabytków - pw. Matki Bożej Królowej Polski, a także dwa położone we wpisanym do rejestru zabytków układzie urbanistycznym dzielnicy Nowa Huta, pw. Matki Bożej Częstochowskiej i pw. Najświętszego Serca Pana Jezusa.

Podjęte analizie przestrzenie przykościelne rzadko urządzone zostały jako czytelne kompozycje ogrodowe, a w znacznej części charakteryzują się przypadkowością. Zarówno elementy małej architektury, jak i symbole religijne rozmieszczone zostały bez uwzględnienia zasad kompozycyjnych. Na poddanych analizie terenach najliczniej występują drewniane krzyże i kapliczki. Elementami charakterystycznymi dla danego miejsca jest ołtarz polowy w kościele pw. Matki Bożej Królowej Polski, sadzawka z rzeźbą św. Jana Chrzciciela przed kościołem pw. Miłosierdzia Bożego czy stacje drogi krzyżowej w formie płaskorzeźb umieszczonych na ogrodzeniu kościoła pw. Matki Bożej Nieustającej Pomocy. W wielu obiektach wprowadzone oświetlenie ma niskie walory estetyczne, ma postać typowych lamp ulicznych bądź reflektorów podświetlających zieleń lub bryłę kościoła. Nagromadzenie detali architektonicznych i nawarstwienie stylowe powoduje wrażenie chaosu przestrzennego, dysharmonii oraz braku dbałości o estetykę.

Założenia sakralne są w większości ogrodzone. Wśród typów ogrodzeń najczęściej występują ogrodzenia składające się z metalowych prefabrykowanych przęsęł bądź metalowych 
siatek. Wśród nieogrodzonych kościołów znajduje się kościół pw. Matki Bożej Królowej Polski, pw. św. Maksymiliana Marii Kolbego i pw. św. Józefa. Dzięki temu, że nie są one ogrodzone, płynnie łączą się z otaczającą je przestrzenią, dając jednocześnie wrażenie bardziej dostępnych i otwartych, również w kontekście metafizycznym. Kościół pw. Miłosierdzia Bożego i pw. Najświętszego Serca Pana Jezusa mogą być rozpatrywane w tym kryterium dwojako, ponieważ są one częściowo oddzielony ogrodzeniem i roślinnością od otoczenia, a częściowo na nie otwartym.

W większości założeń nawierzchnie pełnią rolę jedynie funkcjonalną i użytkową. Najczęściej wykorzystywanym materiałem nawierzchniowym jest kostka brukowa, zwykle w kolorze czerwonym i szarym, a także płyty betonowe. Wyjątkiem jest teren otaczający kościół pw. Matki Bożej Królowej Polski, gdzie zastosowano nieregularne płyty z kamienia naturalnego. Stan techniczny nawierzchni jest dobry, jedynie w kościele pw. św. Maksymiliana Marii Kolbego można zauważyć nierówności, ubytki oraz przerastanie nawierzchni mchem.

W większości, w przestrzeniach wokół kościołów, rośliny nie tworzą układów kompozycyjnych. Najczęściej rozmieszone są one przypadkowo, bez przestrzegania odpowiedniego doboru gatunkowego oraz nieharmonizujące z otoczeniem. Wśród roślin jedynie niewielka część posiada wymiar symboliczny, który jest niezwykle istotny i celowy w takich założeniach. Analizując rośliny, zostały one podzielone na dwie grupy, pierwszą z nich stanowią drzewa, drugą natomiast krzewy, byliny i rośliny zielne. Stosowane drzewa zazwyczaj mają charakter izolacyjny i sadzone są wzdłuż granic terenów przykościelnych. Najczęściej stosowane są rośliny iglaste, świerki, sosny, żywotniki czy cisy. Wśród drzew liściastych najczęściej spotykane są lipy, dęby, jesiony czy brzozy. Analiza grupy krzewów, bylin i roślin zielnych wykazała, że są to rośliny spotykane w parkach i ogrodach przydomowych, między innymi barwinek pospolity, bukszpan wieczniezielony, berberys, jałowiec, ligustr pospolity, żywotnik czy róża. Jedynie kilka z nich posiada znaczenie symboliczne, wśród nich należy wymienić barwinek - wierność, bukszpan - nadzieja zbawienia, jałowiec - opieka Boża, róża - męka Chrystusa. Najczęściej stosowanymi bylinami i roślinami zielnymi są aksamitki, bratki, dąbrówki, pelargonie i fiołki. Wśród analizowanych obiektów wyróżnia się kościół pw. św. Józefa i pw. św. Matki Bożej Nieustającej Pomocy. Pierwszy z nich, otoczony Plantami Bieńczyckimi, wyróżnia się bardzo dobrym stanem zieleni, jej pielęgnacją i utrzymaniem. W jego północo-wschodniej części znajduje się również zieleń komponowana w formie niewielkiego wirydarzu uformowanego z bukszpanów, charakterystycznego dla średniowiecznych założeń klasztornych. W północnej części drugiego założenia znajduje się ogród różańcowy, z charakterystycznymi rzeźbami w formie kul i nazw poszczególnych tajemnic różańcowych. Niestety, zastosowana zieleń swoją formą i rozmiarem nie podkreśla wyjątkowości tego miejsca i odwraca uwagę od jego istoty. 
Tabela 2. Analiza przestrzeni wokół kościołów

\begin{tabular}{|c|c|c|c|c|c|}
\hline Lp. & Otoczenie & Ogrodzenie & Nawierzchnia & $\begin{array}{c}\text { Mała } \\
\text { architektura }\end{array}$ & $\begin{array}{l}\text { Symbole } \\
\text { religijne }\end{array}$ \\
\hline 1 & 2 & 3 & 4 & 5 & 6 \\
\hline 1. & $\begin{array}{l}\text { budynki } \\
\text { wielorodzinne } \\
\text { budynki usługowe } \\
\text { budynki oświaty }\end{array}$ & brak & $\begin{array}{l}\text { nieregularne } \\
\text { płyty } \\
\text { z kamienia } \\
\text { naturalnego }\end{array}$ & $\begin{array}{l}\text { - drewniane } \\
\text { ławki } \\
\text { - brak } \\
\text { oświetlenia } \\
\text { - metalowy } \\
\text { trejaż } \\
\text { - kamienne } \\
\text { donice }\end{array}$ & $\begin{array}{l}\text { - pomnik JP II } \\
\text { - dwie kapliczki } \\
\text { - ołtarz polowy }\end{array}$ \\
\hline 2. & $\begin{array}{l}\text { budynki } \\
\text { wielorodzinne } \\
\text { park Tysiąclecia } \\
\text { pętla tramwajowa }\end{array}$ & brak & $\begin{array}{l}\text { szare, } \\
\text { duże płyty } \\
\text { betonowe, } \\
\text { przerośnięte } \\
\text { mchem }\end{array}$ & $\begin{array}{l}\text { - wysokie } \\
\text { lampy par- } \\
\text { kowe }\end{array}$ & $\begin{array}{l}\text { - pomnik JP II } \\
\text { - dwa } \\
\text { drewniane } \\
\text { krzyże }\end{array}$ \\
\hline 3. & $\begin{array}{l}\text { budynki } \\
\text { wielorodzinne } \\
\text { budynki oświaty } \\
\text { budynki usługowe }\end{array}$ & $\begin{array}{l}\text { - siatka } \\
\text { - żywopłot } \\
\text { - częściowo } \\
\text { otwarte }\end{array}$ & $\begin{array}{l}\text { szare, } \\
\text { duże płyty } \\
\text { betonowe }\end{array}$ & $\begin{array}{c}\text { - lampy } \\
\text { parkowe }\end{array}$ & $\begin{array}{l}\text { - drewniany } \\
\text { krzyż } \\
\text { - fontanna } \\
\text { z rzeżbą } \\
\text { z brązu } \\
\text { - trzy figury } \\
\text { z brązu }\end{array}$ \\
\hline 4. & $\begin{array}{l}\text { budynki } \\
\text { wielorodzinne } \\
\text { park Szwedzki } \\
\text { budynki oświaty }\end{array}$ & $\begin{array}{l}\text { - brązowe, } \\
\text { metalowe, } \\
\text { rzeźbione, } \\
\text { - słupy z cegły }\end{array}$ & $\begin{array}{l}\text { szara, } \\
\text { czerwona, żółta } \\
\text { kostka brukowa }\end{array}$ & $\begin{array}{l}\text { - lampy par- } \\
\text { kowe } \\
\text { - kosze na } \\
\text { śmieci }\end{array}$ & $\begin{array}{l}\text { - dwa } \\
\text { drewniane } \\
\text { krzyże }\end{array}$ \\
\hline 5. & $\begin{array}{l}\text { budynki } \\
\text { wielorodzinne } \\
\text { były pas startowy } \\
\text { budynki oświaty }\end{array}$ & $\begin{array}{l}\text { - szare, } \\
\text { metalowe, } \\
\text { proste }\end{array}$ & $\begin{array}{l}\text { szara, czerwona } \\
\text { kostka brukowa } \\
\text { ułożona we } \\
\text { wzór }\end{array}$ & $\begin{array}{l}\text { - stylizowane } \\
\text { ławki } \\
\text { - drewniane } \\
\text { trejaże }\end{array}$ & $\begin{array}{l}\text { - metalowy } \\
\text { krzyż, } \\
\text { - metalowa } \\
\text { dzwonnica }\end{array}$ \\
\hline 6. & $\begin{array}{l}\text { budynki } \\
\text { wielorodzinne } \\
\text { budynki usługowe } \\
\text { pętla tramwajowa }\end{array}$ & $\begin{array}{l}\text { - czarne, } \\
\text { metalowe, } \\
\text { rzeźbione } \\
\text { - słupy } \\
\text { z klinkieru }\end{array}$ & $\begin{array}{l}\text { czerwona } \\
\text { kostka brukowa }\end{array}$ & $\begin{array}{r}\text { - stylizowane } \\
\text { oświetlenie }\end{array}$ & $\begin{array}{l}\text { - „ogród } \\
\text { różańcowy”, } \\
\text { - stacje drogi } \\
\text { krzyżowej } \\
\text { - figura Jezusa } \\
\text { w koronie }\end{array}$ \\
\hline 7. & $\begin{array}{l}\text { budynki } \\
\text { wielorodzinne } \\
\text { budynki usługowe } \\
\text { budynki przemysłowe } \\
\text { planty Bieńczyckie }\end{array}$ & brak & $\begin{array}{l}\text { wielobarwna } \\
\text { prostokątna } \\
\text { kostka brukowa }\end{array}$ & $\begin{array}{c}\text { - stojaki na } \\
\text { rowery } \\
\text { - lampy } \\
\text { parkowe }\end{array}$ & brak \\
\hline
\end{tabular}


cd. tab. 1

\begin{tabular}{|c|c|c|c|c|c|}
\hline 1 & 2 & 3 & 4 & 5 & 6 \\
\hline 8. & $\begin{array}{l}\text { budynki } \\
\text { wielorodzinne } \\
\text { budynki oświaty }\end{array}$ & $\begin{array}{l}\text { - proste, szare, } \\
\text { metalowe } \\
\text { - słupy } \\
\text { betonowe } \\
\text { - częściowo } \\
\text { otwarte }\end{array}$ & $\begin{array}{l}\text { szare, } \\
\text { kwadratowe } \\
\text { płyty betonowe }\end{array}$ & brak & $\begin{array}{l}- \text { krzyż - } \\
\text { pomnik } \\
\text { Obrońców } \\
\text { Krzyża }\end{array}$ \\
\hline 9. & $\begin{array}{l}\text { budynki } \\
\text { jednorodzinne } \\
\text { budynki gospodarcze } \\
\text { rzeka - Młynówka }\end{array}$ & $\begin{array}{l}\text { - ciemnoszare, } \\
\text { metalowe, } \\
\text { proste } \\
\text { - podmurówka } \\
\text { z piaskowca }\end{array}$ & $\begin{array}{l}\text { czerwona } \\
\text { kostka brukowa }\end{array}$ & brak & $\begin{array}{l}\text { - dwa } \\
\text { drewniane } \\
\text { krzyże }\end{array}$ \\
\hline
\end{tabular}

\section{PODSUMOWANIE}

Znaczenie sacrum w przestrzeniach kultu religijnego powinno być podkreślone zarówno przez funkcję, formę, jak i treść. Przeprowadzone analizy wykazały, że funkcje estetyczne mają mniejsze znaczenie niż funkcje użytkowe. Ponadto wymiar symboliczny, zarówno roślin, jak i małej architektury czy form terenowych, został zatracony i pominięty. Zatracona została również klarowna identyfikacja obiektu sakralnego, a jego otoczenia. Nowohuckie kościoły zostały zlokalizowane przypadkowo, a wynikające z tego ograniczenia terenowe i brak powiązań widokowych i kompozycyjnych pozbawiają go roli wymownego znaku przestrzennego. Marginalizowanie otoczenia kościołów widoczne jest głównie przez brak czytelnych układów kompozycyjnych, brak związku otoczenia z architekturą kościoła czy brak wyraźnego układu funkcjonalnego. Przestrzenie przykościelne, zwłaszcza zlokalizowane wśród zwartej tkanki miejskiej, powinny być miejscem oddzielenia sacrum od profanum i podkreślać odrębność zabudowy sakralnej w aktualnym kontekście urbanistycznym i architektonicznym. 

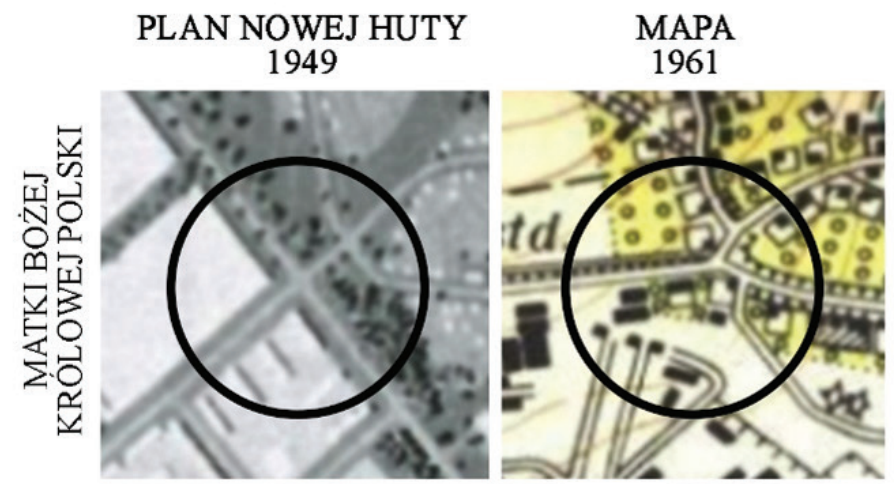

\section{ORTOFOTOMAPA 2017}
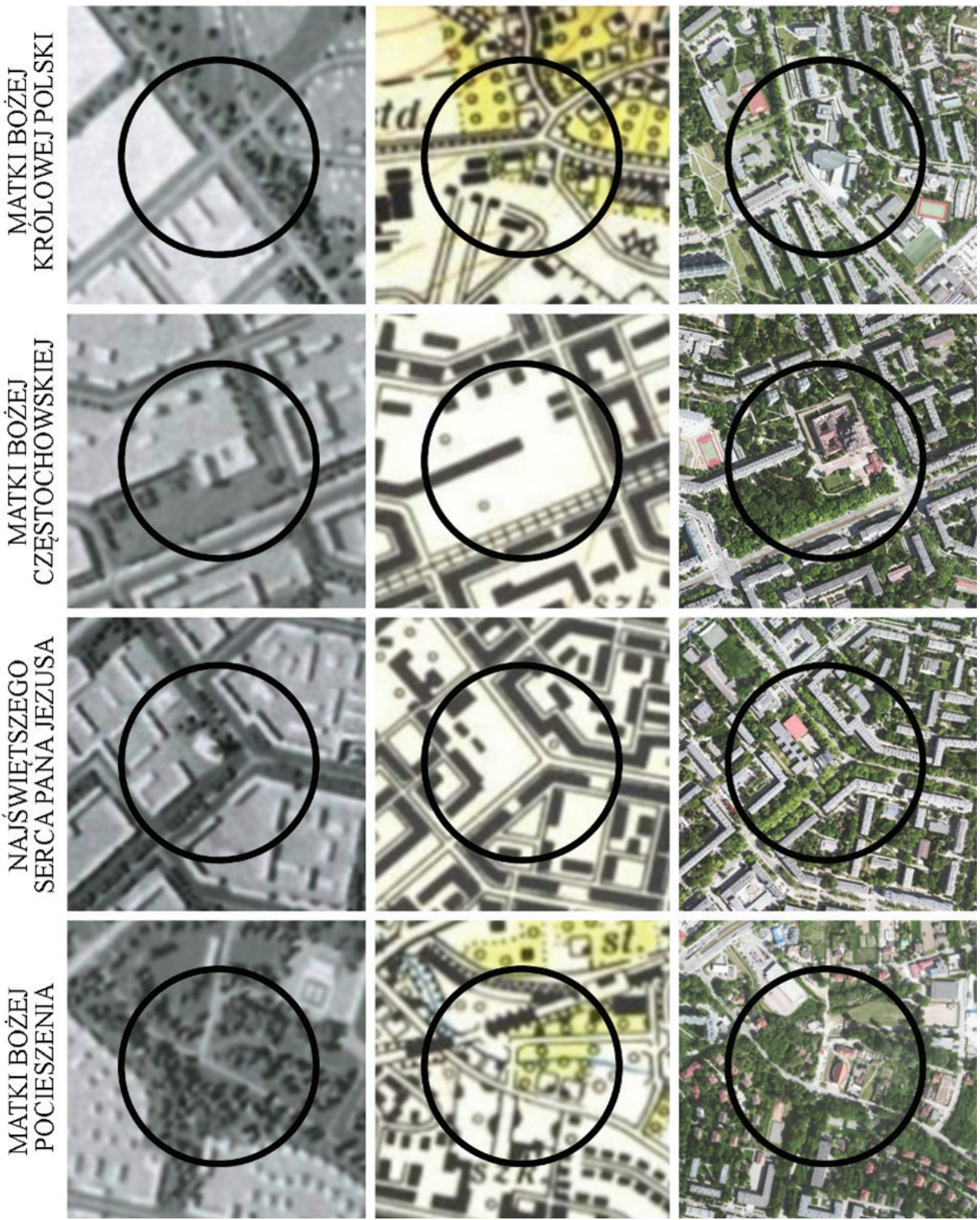

II. 1. Analiza urbanistyczna lokalizacji kościołów (oprac. Agnieszka Wartacz, 2017) 


\section{PRZYPISY}

1 P. Raina, Kościół w PRL. Kościół katolicki a państwo w świetle dokumentów 1945-1989, T. 1, Poznań 1995.

2 J. Gorzelany, Gdy nastał czas budowy Arki. Dzieje budowy kościoła w Nowej Hucie, Paryż 1988, s. 18.

3 F. Musiał, M. Lasota, Kościół zraniony. Proces księdza Lelity i sprawa Kurii krakowskiej, Kraków 2003.

4 J.L. Franczyk, Bóg zamieszkał w Nowej Hucie, [w:] Nowa Huta. Miasto krzyża i pracy, red. J.L. Franczyk, M. Lasota, Kraków 2004.

5 Obecnie ulice Obrońców Krzyża i Ludźmierska, a także Teatr Ludowy.

6 Archiwum parafii w Bieńczycach, Pismo Przedsiębiorstwa Projektowania Budownictwa Miejskiego w Krakowie, Pracownia U, L. dz. U./42/57 r., 24 I 1957.

7 Audycja radiowa z uroczystości poświęcenia krzyża. Zapis fragmentów audycji [w:] Ridan J., Róg Marksa i Obrońców Krzyża, „Karta”, nr 21, 1997, s. 121.

8 DBOR Kraków-Miasto do proboszcza kościoła rzymskokatolickiego w Bieńczycach 14 IV 1960, dokument cytowany w całości [w:] Gorzelany J., op. cit., s. 62.

9 J. Gorzelany, op. cit.

10 J.L. Franczyk, Na fundamencie Krzyża. Kościół katolicki w Nowej Hucie w latach 1949-1989, Kraków 2004, s. 191-203

11 M. Latasiewicz, Parafia Miłosierdzia Bożego Kraków - Wzgórza Krzesławickie 1981-2001, Kraków 2002.

12 N.S. Karsznia, Powstanie parafii i budowa kościoła Matki Bożej Częstochowskiej w Nowej Hucie, Kraków 1997.

13 M. Latasiewicz, Parafia Świętego Brata Alberta Kraków - Nowa Huta 1983-2003, Kraków 2003.

${ }^{14}$ http://www.maryja-mistrzejowice.pl/parafia/akterekcyjny.html (dostęp: 05.11.2017).

15 http://parafia.kalinowe.pl/parafia (dostęp: 05.11.2017).

${ }^{16}$ Kościół Najświętszego Serca Pana Jezusa w Nowej Hucie, „Dziennik Polski”, nr 15, 2003, s. 8.

$17 \mathrm{http}: / /$ encyklopediakrakowa.pl/architektura-i-urbanistyka/swiatynie/125-koscioly/157-kosciol-matki-bozej-pocieszenia.html (dostęp: 05.11.2017). 


\section{LITERATURA}

Franczyk J.L., Na fundamencie Krzyża. Kościół katolicki w Nowej Hucie w latach 1949-1989, Kraków 2004.

Golonka-Czajkowska M., Nowe miasto nowych ludzi. Mitologie nowohuckie, Kraków 2013. Gorzelany J., Gdy nastał czas budowy Arki. Dzieje budowy kościoła w Nowej Hucie, Paryż 1988. Jagło P., Nowa Huta dla Wolnej i Niepodległej, Kraków 2014.

Karsznia N.S., Powstanie parafii i budowa kościoła Matki Bożej Częstochowskiej w Nowej Hucie, Kraków 1997.

Latasiewicz M., Parafia Świętego Brata Alberta Kraków - Nowa Huta 1983-2003, Kraków 2003. Latasiewicz M., Parafia Miłosierdzia Bożego Kraków - Wzgórza Krzesławickie 1981-2001, Kraków 2002.

Musiał F., Lasota M., Kościół zraniony. Proces księdza Lelity i sprawa Kurii krakowskiej, Kraków 2003.

Raina P., Kościół w PRL. Kościół katolicki a państwo w świetle dokumentów 1945-1989, T. 1, Poznań 1995.

Szarek J., Lasota M., Terlicki R., Nowa Huta-miasto walki i pracy, Kraków 2002. 